pheric conditions]. Fotonika - Photonics, 2008, no. 4, pp. 28-30. (Rus.)

12. Topolyansky P.A., Sosnin N.A., Ermakov S.A. Finishnoye plazmennoye uprochneniye - nanotekhnologiya (k 25-letiyu sozdaniya) [Final plasma hardening - nanotechnology (to the 25th anniversary of its creation)]. Tekhnologii uprochneniya, naneseniya pokrytiy $i$ remonta: Teoriya $i$ praktika - Technologies of hardening, coating and repair: Theory and practice, 2012, vol. 2, pp. 344-366. (Rus.)

13. Samotugin S.S, Mazur V.A. Plazmennoye mikro- i nanostrukturirovaniye poverkhnosti instrumental'nykh staley [Plasma micro- and nanostructuring of the surface of tool steels]. Uprochnyayushchiye tekhnologii i pokrytiya - Strengthening technologies and coatings, 2013, no. 4, pp. 29-37. (Rus.)

14. Samotugin S.S., Samotugina Yu.S., Khristenko O.A. Nanotekhnologii v mashinostroyenii: plazmennoyemodifitsirovaniyerez'bonareznogoinstrumenta [Nanotechnologies in mechanical engineering: plasma modification of thread-cutting tools]. Visnik Priazovs'kogo derzhavnogo tekhnichnogo universitetu. Seriia: Tekhnichni nauki-Reporter of the Priazovskyi State Technical University. Section: Technical sciences, 2018, no. 37, pp. 105-114. doi: 10.31498/22256733.37.2018.160266. (Rus.)

15. Samotugin S.S., Samotugina Yu.S., Khristenko O.A., Tkachenko T.K., Lavrinenko V.I. Plazmennoye submikro- i nanostrukturirovaniye instrumenta iz stali KH12M [Plasma submicroand nanostructuring of a tool made of Cr12Mo steel]. Tekhnologiya mashinostroyeniya Mechanical engineering technology, 2020, no. 5, pp. 42-52. (Rus.)

16. Nikolayev A.V. Plazmenno-dugovoy nagrev veshchestva [Plasma-arc heating of matter]. Plazmennyye protsessy $v$ metallurgii i tekhnologii neorganicheskikh materialov - Plasma processes in metallurgy and technology of inorganic materials, 1973, pp. 20-32. (Rus.)

Рецензент: В.В. Суглобов

д-р техн. наук, проф., ДВНЗ «ПДТУ»

Стаття надійшла 27.01.2020

UDC 621.791:669.14.018.256

doi: $10.31498 / 2225-6733.40 .2020 .216163$

(c) Morgay F.V. ${ }^{1}$, Ivanov V.P. ${ }^{2}$, Solidor N.A. ${ }^{3}$

\title{
INVESTIGATION OF CORROSION RESISTANCE OF WELDED FLEXIBLE COMPENSATION ELEMENTS FROM AUSTENITIC STEELS OPERATING IN AGGRESSIVE ENVIRONMENTS
}

The main characteristics of welded flexible compensating elements made of austenitic steels AISI 304 and AISI 316 are considered, and an analysis of the types of corrosion arising during their operation is carried out. Metallographic studies and studies to assess the resistance to pitting and intergranular corrosion have been carried out. Research has been carried out on the chemical composition of materials for the manufacture of metal hoses and bellows expansion joints, as well as research on resistance to corrosion cracking. As a result of the experiments carried out, the effect of heat treatment and the degree of deformation on the corrosion resistance of austenitic steels AISI 304 and AISI 316 in various environments has been determined.

Keywords: flexible compensating elements, stainless steel, metallographic research, corrosion resistance, microplasma welding.

\footnotetext{
${ }^{1}$ PhD cmyденm, SHEI «Priazovskyi state technical university», Mariupol

2 Dsc (Engineering), associate professor, SHEI «Priazovskyi state technical university», Mariupol, ORCID: 0000-0003-3339-7633

3 Cand.Sc. (Engineering), associate professor, SHEI «Priazovskyi state technical university», Mariupol, ORCID: 0000-0002-3861-7933
} 
Моргай Ф.В., Іванов В.П., Солідор Н.А. Досліджсння корозійной стійкості зварних гнучких компенсаційних елементів з аустенітних сталей, що експлуатуються в агресивних середовищах. Розглянуто основні характеристики зварних гнучких компенсаційних елементів з аустенітних сталей AISI 304 і AISI 316 і здійснено аналіз видів корозії, що виникають при їх експлуатації. В якості найбільш ймовірних причин прояву місцевої корозї̈ розглянуті неоднорідний напружений стан і склад корозійного середовища, в якому здійснюється зберігання і експлуатачія виробів. Запропоновано використання термічної обробки як ефективного способу зниження рівня внутрішніх напружень. Проведено металографічні дослідження і дослідження з очінки стійкості до піттингової і міжкристалітної корозії. Проведено дослідження хімічного складу матеріалів для виготовлення металорукавів і сильфонних компенсаторів, а також дослідження стійкості проти корозійного розтріскування. Встановлено, що в умовах високих показників вологості $i$ вмісту хлориду натрію в атмосфері сталь марки AISI 316 має більш високі показники стійкості до місиевої корозї̈, а стійкість сталей AISI 304 і AISI 316 до корозійного розтріскування виявилася задовільною. Проведені дослідження щодо впливу термообробки на корозійну стійкість зразків зварних гнучких компенсаиійних елементів в 60\%-му розчині хлориду натрію. Встановлено в результаті, що відпустка при температурі $550^{\circ} \mathrm{C}$ для всіх попередньо деформованих зразків сталей AISI 304 i AISI 316 призводить до зниження інтенсивності корозійних процесів, що пов'язано зі зменшенням рівня внутрішніх напружень в металі. В результаті проведених експериментів визначено параметри оптимального режиму термічної обробки на корозійну стійкість зварних гнучких компенсаційних елементів із аустенітних сталей, щчо експлуатуються в агресивних середовищах.

Ключові слова: гнучкі компенсачійні елементи, нержавіюча сталь, металографічні дослідження, корозійна стійкість, мікроплазмове зварювання.

\begin{abstract}
Моргай Ф.В., Иванов В.П., Солидор Н.А. Исследование коррозионной стойкости сварных гибких компенсационных элементов из аустенитных сталей, эксплуатирующихся в агрессивных средах. Рассмотрены основные характеристики сварных гибких компенсационных элементов из аустенитных сталей AISI 304 и AISI 316 и осуществлен анализ видов коррозии, возникающих при их эксплуатаџии. Проведены металлографические исследования и исследования по оценке стойкости $\kappa$ питтинговой и межкристаллитной коррозии. Проведены исследования химического состава материалов для изготовления металлорукавов и сильфонных компенсаторов, а также исследования стойкости против коррозионного растрескивания. В результате проведенных экспериментов определены влияние термической обработки и степени деформации на коррозионную стойкость аустенитных сталей AISI 304 и AISI 316 в различных средах.
\end{abstract}

Ключевые слова: гибкие компенсачионные элементы, нержавеющая сталь, металлографические исследования, коррозионная стойкость, микроплазменная свар$\kappa a$.

Description of the problem. Austenitic chromium-nickel steels are one of the main materials in the manufacture of flexible compensating elements (FCE), where aggressive technological environments prevail.

Despite the extensive a priori information, the reasons for the corrosion processes of chromiumnickel steels and metal of welded joints that occur in chloride and alkaline media, both without and with temperature-force action, have not yet been sufficiently clarified, which complicates the development of recommendations for reducing the degree of equipment destruction and devices.

A feature of austenitic chromium-nickel steels is their tendency to pitting corrosion, especially under conditions of exposure to chlorine ions (i.e., in a maritime climate). In addition, the surface condition has a great influence on the corrosion resistance of steels. The presence on the surface of the steel of traces of cleaning, scratches, rough marks, traces of raster and other defects reduces the quality of the passive film, which is responsible for the corrosion resistance of steels, and facilitates the for- 


\section{p-ISSN: 2225-6733; e-ISSN: 2519-271X}

mation of foci of corrosion and their further development during operation. The best type of processing is surface polishing, during which the smallest irregularities of the surface are smoothed, scratches are removed, the shine is sharply increased and the decorative and presentation of the products is improved.

Analysis of recent research and publications. It is known that the tendency of steel structures to fracture in aggressive technological solutions is mainly due to the properties of the metal, the stressed state of the product, and the activity of the medium [1,2]. The composition and structure of the heat-affected zone of the welded joint depend on the thermal deformation and thermomechanical welding cycles. In this case, zones with different properties appear in the metal [3, 4]. In addition, an unfavorable change in the stress state of the metal is also a factor that enhances the effect of a corrosive environment [5].

FCE are manufactured using microplasma welding and subsequent deformation into a corrugation of a given diameter. The nature of corrosion damage and their location (far from the welded seam and HAZ) allow us to conclude that no unfavorable changes occur in the weld metal and the near-weld zone during welding. Damage is observed not over the entire surface of the product, but in the most defective areas with a high level of residual stresses between stiffeners (corrugations). It is known that defective areas of crystals (high- and low-angle boundaries, dislocations), the electrode potential of which is underestimated, are anodes and are destroyed by corrosion [6]. Previous studies have shown that austenitic steel grade AISI 316 has higher resistance to local corrosion, and the resistance of steels AISI 304 and AISI 316 to stress corrosion cracking was found to be satisfactory [2,6]. In addition, studies of finished products have shown that there is accelerated corrosion of metal hoses from the outside, which is already detected during storage of products in the warehouse of the enterprise. It should be noted that the air in the storage room contains an increased salt content and is characterized by high humidity. At the same time, condensate settles in the depressions of the metal hoses, which enhances the pitting corrosion of products.

Purpose of the article - development of measures to improve the technology of manufacturing welded flexible compensating elements made of austenitic stainless steels, allowing increasing the operational resistance of products when operating in various environments and loading conditions.

Presentation of the main material. One of the most probable causes of local corrosion (spots, pits, ulcers) of the products under consideration is the inhomogeneous stress state and the composition of the corrosive environment. The stress state affects the corrosion behavior of the metal due to the following phenomena:

a) imparting additional energy to the metal, which causes a decrease in its thermodynamic stability; the deformed metal has a lower work function, i.e., the bond is weakened and, consequently, it is easier for the $\mathrm{Me}+$ ion to leave the lattice in comparison with an undeformed metal;

b) violations under the influence of deformation of the continuity and protective properties of surface films; the film formed on a stressed or deformed metal at the initial moment of the action of the electrolyte contains more cracks and a larger size than on an undeformed metal, as a result of which the potential can be flattened;

c) an increase in the degree of inhomogeneity associated with the appearance of crystal lattice defects and new anode phases under the action of deformation.

The voltages applied in the concentrators shift the electrode potential to the negative side and increase the rate of anodic dissolution of the metal.

In general, the danger of the effect of the stress state on corrosion is not an increase in general corrosion, but a change in its nature, in its transformation from uniform to local. Local anodic areas and corrosive paths can be divided into initial ones, which are already present in the metal without a stressed state, and arising under the action of a stressed state.

The first group includes microstructural and chemical inhomogeneities of the alloy, grain boundaries, lattice and structure defects (dislocations, their accumulations, micro-enrichment of dissolved atoms on crystal defects), local disturbances of the film, and initial microcracks.

The second group includes moving lattice defects (deformable metal) at the crack tip, microsegregations of atoms of the dissolved component on moving lattice defects at the crack tip, new corrosion-unstable phases that arise during deformation at the crack tip, areas under film breaks formed during metal deformation.

One of the most effective ways to reduce the level of internal stresses in alloys is heat treatment. 


\section{p-ISSN: 2225-6733; e-ISSN: 2519-271X}

In this connection, the work carried out research on the effect of heat treatment on the corrosion resistance of stainless steel of the austenitic class AISI 316 in $60 \%$ sodium chloride solution. After tests for electrochemical corrosion in a salt solution, the weight loss of the AISI 316 steel samples without heat treatment was $0.027 \mathrm{~g}$.

Samples of AISI 316 steel were tempered at a temperature of $200^{\circ} \mathrm{C}$ in order to reduce internal stresses. The heating exposure was 30, 60, 90 and 120 minutes. After the tempering, cooling was carried out in calm air. All the samples under study after heat treatment were checked by the magnetic method, as a result of which the presence of magnetic phases was not detected. Then the samples were subjected to electrochemical corrosion in a $60 \%$ aqueous solution of sodium chloride $(\mathrm{NaCl})$.

In the course of the research, it was found that the corrosion resistance of AISI 316 steel samples after low tempering at different holding times in the range from 30 to 120 min changes ambiguously (Fig. 1).

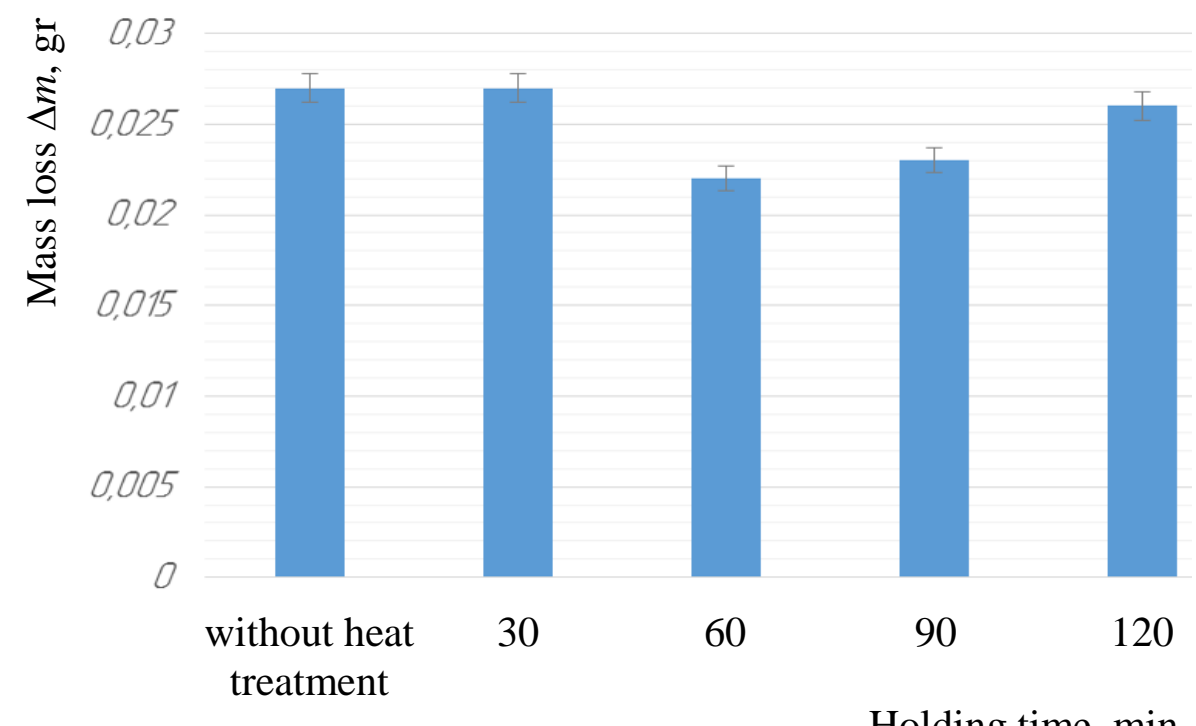

Fig. 1 - Corrosion resistance of AISI 316 steel specimens versus low tempering holding time $(\mathrm{NaCl} 60 \%)$

Thus, a decrease in the intensity of corrosion destruction of AISI 316 steel was observed after tempering at $200^{\circ} \mathrm{C}$ for $60 \mathrm{~min}$, and the intensification of corrosion processes was observed at exposures of $90 \mathrm{~min}$ or more, which is confirmed by the indicators of changes in the mass of the samples under study and by studying their macrostructure.

As a result of the research, the features of the macrostructure of the studied samples from AISI 316 steel were studied. The macrostructure of the studied samples after electrochemical corrosion in a saline solution is shown in Fig. 2.

It has been found that AISI 316 steel samples are less susceptible to electrochemical corrosion after tempering at a temperature of $200^{\circ} \mathrm{C}\left(\tau_{h}=60 \mathrm{~min}\right)$. This is probably due to the fact that, at a given temperature and holding time, internal stresses obtained as a result of preliminary deformation are completely removed in steel, and corrosion proceeds at the lowest rate.

According to the data obtained, with an increase in the holding time over $60 \mathrm{~min}$, an increase in the corrosion rate of the steel under study occurs, which is probably due to an increase in the concentration of impurities near dislocations. In this case, upon reaching the solubility limit near the dislocation core, dispersed precipitates of the second phase (carbides) can form, which are anodes and provoke the activation of corrosion processes [6]. At the same time, on the surface of the metal, the formation of a large number of small disconnected lesions (pits) is observed, which merge in some places, forming ulcers. The formation of pits on the surface of stainless steels occurs mainly near particles of non-metallic inclusions, primarily oxides and carbides, as well as accumulations of dislocations and defects in machining. Pitting begins with the initiation of a groove near the inclusion, as it increases, separation occurs first, and then gradual destruction of the inclusion. The pitting surface dissolves in a 


\section{p-ISSN: 2225-6733; e-ISSN: 2519-271X}

corrosive environment at a rate of several thousand monolayers per second, in contrast to the adjacent metal area. It should be noted that pitting corrosion is extremely dangerous, since at low weight loss, the metal is exposed to deep lesions, in a short time leading to through defects.

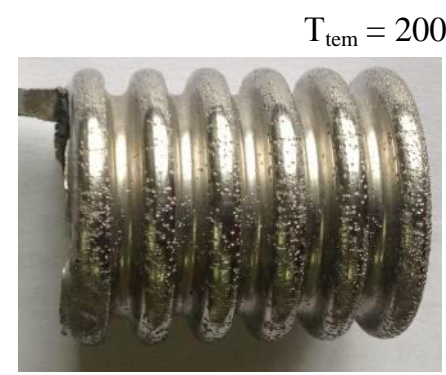

$30 \min$

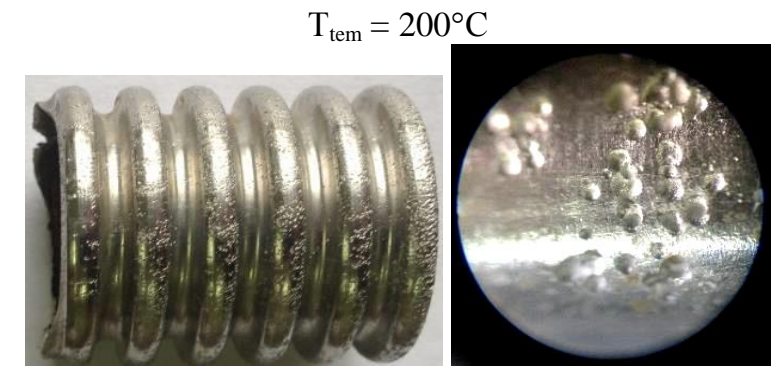

$90 \min$

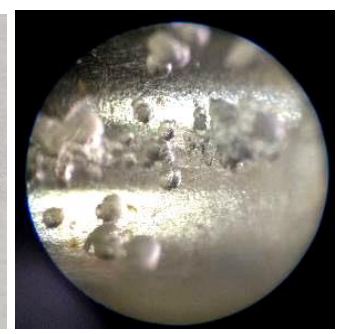

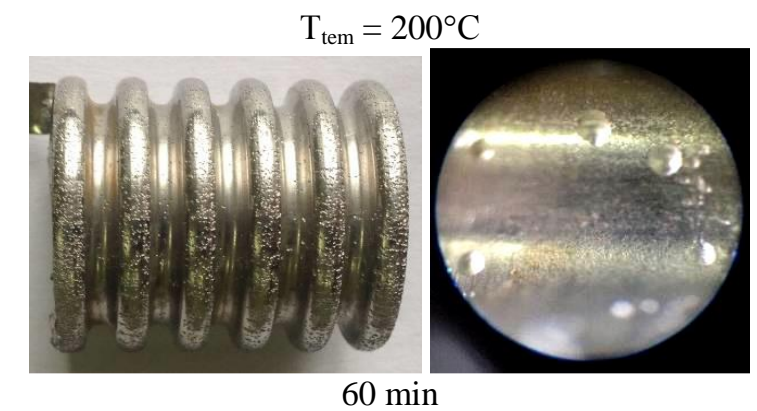

$60 \min$

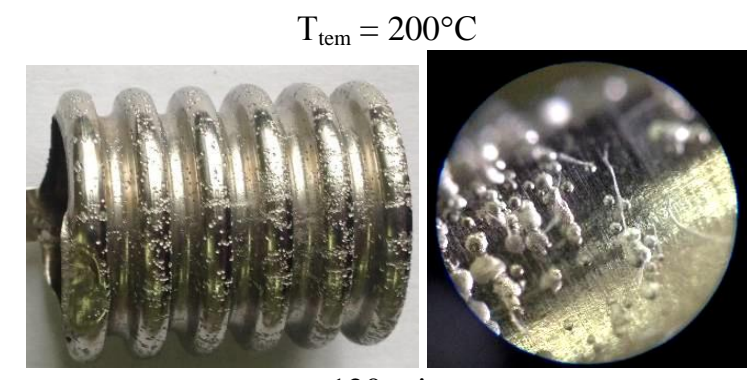

$120 \mathrm{~min}$

Fig. 2 - Appearance and microstructure of samples after testing

Based on the data obtained, for metal hoses made of steel of the austenitic class AISI 316, in order to reduce the tendency to corrosive destruction (pitting corrosion), it is recommended to carry out tempering to relieve internal stresses at a temperature of $200^{\circ} \mathrm{C}$ for $60 \mathrm{~min}$. Heat treatment (tempering) of AISI 316 steel at a temperature of $200^{\circ} \mathrm{C}$ was carried out in an electric muffle furnace FEM-0.05/1100 (Fig. 3). The furnace is equipped with a TM-403 thermostat and a chromel-alumel thermocouple. The holding time of the samples was 30, 60, 90, and $120 \mathrm{~min}$. Cooling of steels after tempering was carried out in calm air.

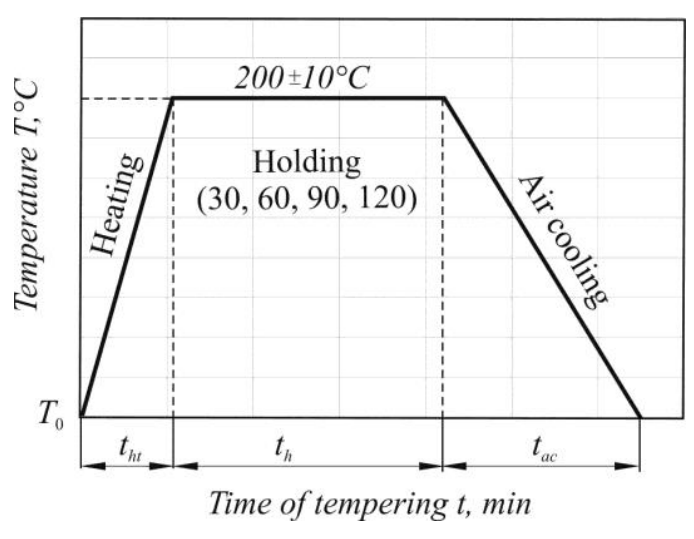

a

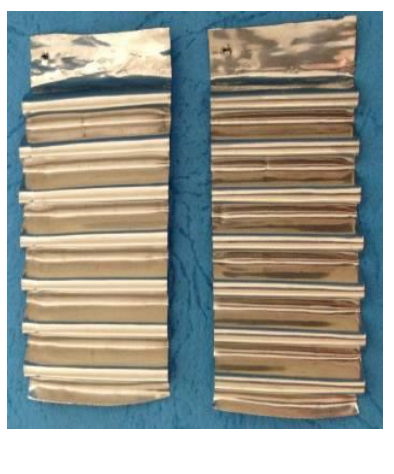

b

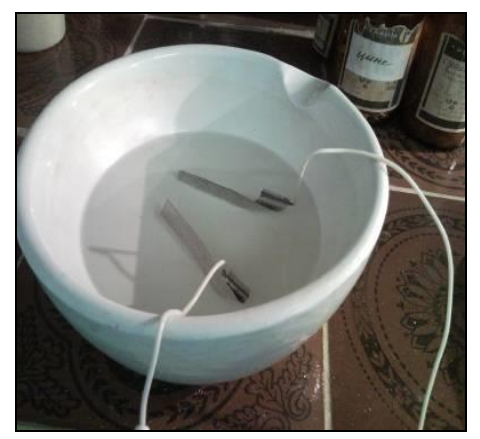

C

Fig. 3 - Schematic diagram of the heat treatment regime for AISI 316 steel (a) and the appearance of samples (b) during tests for electrochemical corrosion (c)

The simplest and most accessible method for determining the corrosion resistance of metals in electrolytes is the open vessel test (Fig. 3), which allows you to investigate most of the corrosion indicators. 
Electrochemical corrosion tests were performed according to GOST 9.514-99 in 60\% sodium chloride $(\mathrm{NaCl})$ solution. A photo of the tests is shown in Fig. 3, c. The main test parameters: voltage $U=3 \mathrm{~V}$, current $I=1.5 \mathrm{~A}$. After testing, the samples were washed with water, dried, degreased and weighed. The determination of the weight loss of the samples was carried out every 5 minutes of testing by weighing the samples using an electric equal-arm balance model VLR-200 (TU 25.06.1131-75). The total test time was 10 minutes. In fig. 4 shows a graph of the change in the weight loss of the samples of the studied steels depending on the degree of deformation.

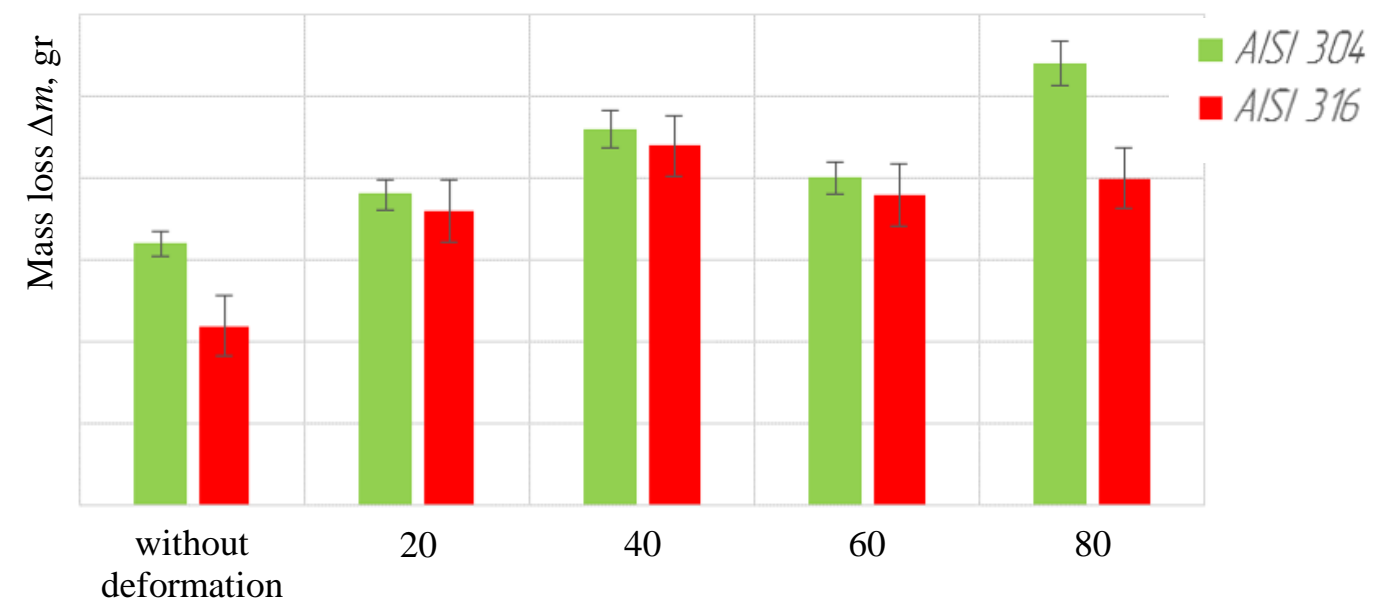

Deformation degree $\varepsilon, \%$

Fig. 4 - Effect of the degree of deformation of AISI 304 and AISI 316 steels on their corrosion resistance

Also, the work investigated the effect of tempering at a temperature of $550{ }^{\circ} \mathrm{C}$, carried out after stretching the samples with various degrees of deformation, on their corrosion resistance in a sodium chloride solution. The research results are shown in Fig. 5.

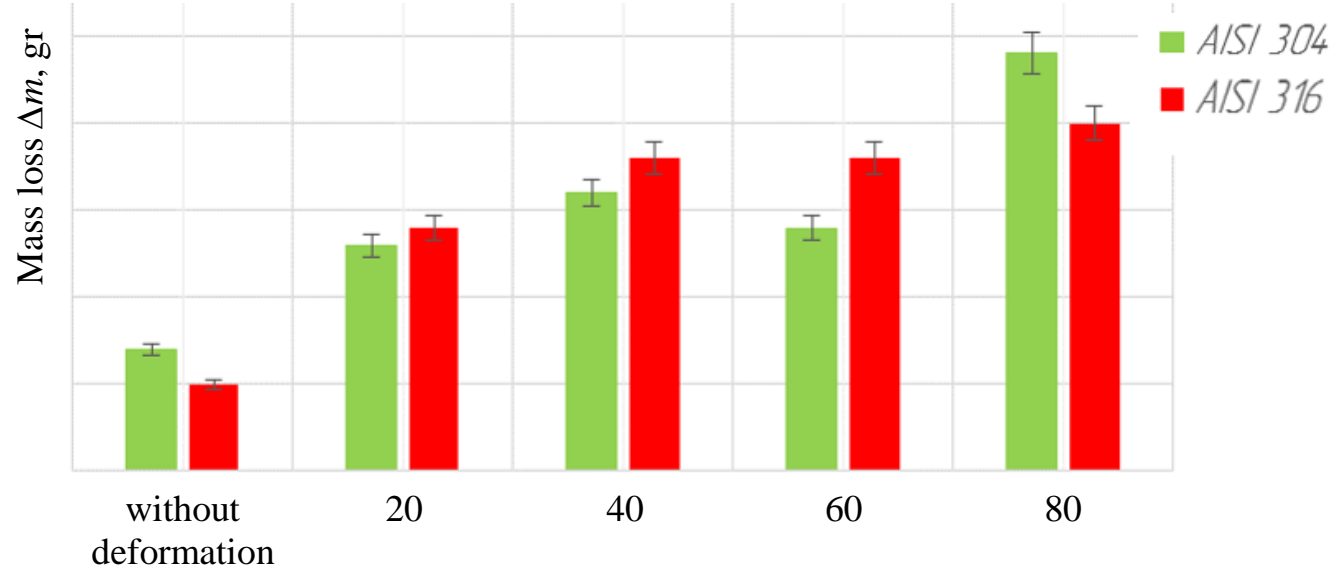

Deformation degree $\varepsilon, \%$

Fig. 5 - Corrosion resistance of samples of steels AISI 304 and AISI 316, pre-tensioned with different degrees of deformation, after tempering at $550^{\circ} \mathrm{C}$

The research results indicate the ambiguous influence of the degree of deformation of the FCE samples on the corrosion resistance of the studied steels. In the investigated range of the degree of deformation in both cases, a local maximum was found for a value of $40 \%$, above which the resistance of the samples to electrochemical corrosion increased to $60 \%$. A further increase in the degree of deformation predictably led to a repeated decrease in the corrosion resistance of the samples of the studied steels, both without heat treatment and after tempering. 
Despite this circumstance, research results have shown that tempering at a temperature of $550^{\circ} \mathrm{C}$ for all pre-deformed samples of AISI 304 and AISI 316 steels leads to a decrease in the intensity of corrosion processes, which is associated with a decrease in the level of internal stresses in the metal. It was found that the favorable effect of thermal tempering on corrosion resistance was more pronounced for steel AISI 304 than for steel AISI 316.

\section{Conclusions}

1. In the course of the study, it was found that as a result of the combined action of the stress state and the influence of the environment, flexible compensating elements made of austenitic steels AISI 304 and AISI 316 exhibit instability to pitting corrosion. The main destabilizing factors that promote pitting and other local types of corrosion are grain boundary carbide deposition and twinning during liner fabrication and operating conditions.

2. The effect of tempering at a temperature of $200^{\circ} \mathrm{C}$ with different holding times for $30,60,90$ and $120 \mathrm{~min}$ on the corrosion resistance of stainless steel of the austenitic class AISI 316 in a $60 \%$ sodium chloride solution was investigated. It has been established that the corrosion resistance of AISI 316 steel samples varies ambiguously. Thus, the minimum rate of corrosion destruction is observed in the samples after low tempering at a holding time of $60 \mathrm{~min}$, and the maximum rate at a holding time of 90 minutes or more. A decrease in the rate of corrosion destruction of AISI 316 steel after tempering at $200^{\circ} \mathrm{C}$ for $60 \mathrm{~min}$ is due to a decrease in the elastic-plastic inhomogeneity of the metal and a decrease in the level of internal stresses.

3. Based on the data obtained for metal hoses made of steel of austenitic class AISI 316, in order to reduce the tendency to corrosive destruction (pitting corrosion), it is recommended to conduct tempering to relieve internal stresses at a temperature of $200^{\circ} \mathrm{C}$ for $60 \mathrm{~min}$.

\section{References:}

1. Steklov O.I. Prochnost' svarnykh konstruktsii v agressivnykh sredakh [Strength of welded structures in corrosive environments]. Moscow, Mashinostroenie Publ., 1976. 200 p. (Rus.)

2. Naukovo-tekhnichnii zvit. Vstanovlennia prichin poshkodzhennia rukaviv metalevikh iz nerzhaviiuchoï stali [Scientific and technical report. Establishing the causes of damage to stainless steel metal sleeves]. Kiev, 2014. 59 p. (Ukr.)

3. Saptarshi S., Mukherjee M. Pal T.K. Microstructure, texture, and mechanical property analysis of gas metal arc welded AISI 304 austenitic stainless steel, JMEPEG, 2015, Vol. 24, pp. 1125-1139. doi: 10.1007/s11665-014-1374-0.

4. Tsutsumi Y., Nishikata A., Tsuru T. Pitting corrosion mechanism of Type 304 stainless steel under a droplet of chloride solutions, Corrosion Science, 2007, Vol. 49 (3), pp. 1394-1407. doi: 10.1016/j.corsci.2006.08.016.

5. Alimov V.I., Duriagina Z.A. Koroziia ta zakhist metaliv vid koroziï [Corrosion and protection of metals from corrosion]. Donetsk-Lviv, TOV «Skhidnii vidavnichii dim» Publ., 2012. 328 p. (Ukr.)

6. Solidor N.A., Ivanov V.P., Morgay F.V., Nosovsky B.I. Investigation of corrosion resistance welds metal hose made of steels AISI 304 and AISI 316, Eastern-European Journal of Enterprise Technologies, 2015, Vol. 76 (4/5), pp. 33-39. doi: 10.15587/1729-4061.2015.47035.

\section{Перелік використаних джерел:}

1. Стеклов О.И. Прочность сварных конструкций в агрессивных средах / О.И. Стеклов. - М. : Машиностроение, 1976. - 200 с.

2. Встановлення причин пошкодження рукавів металевих із нержавіючої сталі. Науковотехнічний звіт - IEЗ ім. Є.О. Патона, м. Київ, 2014 р. - 59 с.

3. Saptarshi S. Microstructure, texture, and mechanical property analysis of gas metal arc welded AISI 304 austenitic stainless steel / S. Saptarshi, M. Mukherjee, T.K. Pal // Journal of Materials Engineering and Performance. - 2015. - Vol. 24. - Pp. 1125-1139. Mode of access : DOI: 10.1007/s11665-014-1374-0.

4. Tsutsumi Y. Pitting corrosion mechanism of Type 304 stainless steel under a droplet of chloride solutions / Y. Tsutsumi, A. Nishikata, T. Tsuru // Corrosion Science. - 2007. - Vol. 49 (3). Pp. 1394-1407. Mode of access : DOI: 10.1016/j.corsci.2006.08.016. 
5. Алімов В.І. Корозія та захист металів від корозії / В.І. Алімов, 3.А. Дурягіна. - ДонецькЛьвів : ТОВ «Східний видавничий дім», 2012. - 328 с.

6. (2015) Investigation of corrosion resistance welds metal hose made of steels AISI 304 and AISI 316 / N.A. Solidor, V.P. Ivanov, F.V. Morgay, B.I. Nosovsky // Eastern-European Journal of Enterprise Technologies. - 2015. - Vol. 76 (4/5). - Pp. 33-39. Mode of access : DOI: 10.15587/1729-4061.2015.47035.

Reviewer: V.I. Shchetinina

D.Sc. in Engineering, professor, SHEI «PSTU»

The article was admitted on 15.03.2020

UDC 621.762.4

doi: $10.31498 / 2225-6733.40 .2020 .216165$

(C) Abayev I.I."

\section{WAYS OF INCREASING THE DENSITY, STRENGTH AND TRIBOTECHNICAL CHARACTERISTICS OF ANTIFRICTION POWDER COMPOSITIONS}

The article considers the issues of obtaining high-density powder compositions by reducing the amount of process lubricant in the charge or its complete exclusion from the charge. It is shown that when technological grease is introduced into the charge under conditions of high pressing pressure, it prevents compaction of the powder charge. This is due to the negative effect of lubrication on the evacuation of air in the press. Lubrication enveloping the particles of metal powders at high sealing pressures closes the air outlets from the area of the compaction seal. In the case of applying grease to the die wall, the negative effect of lubrication at high pressing pressures is reduced to zero. The introduction of lubricant into the powder charge is justified only in the case of pushing the press out of the matrix, the lubricant reduces the pushing force. Reducing the amount of lubricant (zinc stearate) to a reasonable minimum at high compression pressures contributes to the compaction of the charge, i.e. $d \rho / d p$ remains a positive value. Experimental data show that the use of a minimum amount of lubricant helps to increase the density of the presses, and hence all the mechanical properties of the sintered powder compositions. To increase the competitiveness of powder compositions with cast materials of similar composition, it is necessary to use the technology of double pressing and sintering. However, double pressing technology doubles the product production cycle. Therefore, further extensive research is required to fully solve the problem of obtaining non-porous powder compositions by single pressing and sintering.

Keywords: density, strength, tribotechnical characteristics, powder composition, compaction pressure, the lubricant, the sealing performance.

Абаєв І.І. Шляхи підвищення щільності, міцності та триботехнічних характеристик антифрикційних порошкових композицій. $У$ статті розглядаються питання отримання високоплотних порошкових композицій шляхом зниження кількості технологічного мастила в шихті або повного виключення ї̈ з иихти. Показано, щя при введенні в шихту технологічного мастила в умовах положення високого тиску пресування, вона перешкоджає ущільненню порошкової шихти. Це пояснюється негативним впливом мастила на евакуацію повітря, щзо знаходиться в порошку. Мастило, огортаючи частки металевих порошків при високому тиску ущільнення, закриває шляхи виходу повітря з області ущільнення пресування. У разі

\footnotetext{
*applicant, Azerbaijan Technical University, Baku, Azerbaijan, irmik.abayev@gmail.com
} 